\title{
Tritrichomonas foetus and Trichomonas vaginalis: the pattern of inactivation of hydrogenase activity by oxygen and activities of catalase and ascorbate peroxidase
}

\author{
Madhu Page-Sharp, Carolyn A. Behm and Geoffrey D. Smith \\ Author for correspondence: Geoffrey D. Smith. Tel: +61 6249 2843. Fax: +616249 0313. \\ e-mail: Geoffrey.Smith@anu.edu.au
}

Division of Biochemistry and Molecular Biology, School of Life Sciences, Faculty of Science, The Australian National University, Canberra, ACT 0200, Australia

\begin{abstract}
The concentration-dependence of the inhibition of whole-cell hydrogen formation by oxygen has been measured in the trichomonads Trichomonas vaginalis and Tritrichomonas foetus, and compared with the oxygen inhibition of the in situ hydrogenase activity as measured by a tritium exchange assay. The inhibition profiles closely paralleled each other, suggesting that hydrogenase is the primary site of inhibition of anaerobic fermentative metabolism. In addition the inhibition profile for isolated hydrogenosomes was measured and shown to be similar to that for whole organisms. Ascorbate peroxidase was shown to be present in both organisms whereas catalase was confirmed to be present only in Tritr. foetus. The kinetic parameters of both enzymes were measured and their respective roles in oxygen protection discussed.
\end{abstract}

Keywords: Tritrichomonas foetus, Trichomonas vaginalis, hydrogenase, catalase, ascorbate peroxidase

\section{INTRODUCTION}

Trichomonads are a group of flagellated protozoans which differ from most other eukaryotes in their energy metabolism. The nature and subcellular organization of their bioenergetic systems have similarities to those of certain prokaryotes. A unique feature of trichomonads is the presence of hydrogenosomes and the absence of mitochondria. Amongst this group, Trichomonas vaginalis and Tritrichomonas foetus are widely studied. Trich. vaginalis is a sexually transmitted human parasite, infecting the urinogenital tract of both men and women; Tritr. foetus is a sexually transmitted parasite in cattle.

Trichomonads are microaerophilic organisms and even traces of oxygen influence their fermentative capability. At least part of the reason for this stems from the fact that they form hydrogen as a fermentative electron sink and the formation of hydrogen has been reported to be oxygen-sensitive (Lloyd \& Kristensen, 1985; Ellis et al., 1992). The measured oxygen tension in the vagina is significant (the physiological oxygen concentration range to which Trich. vaginalis could be exposed is $15-56 \mu \mathrm{M}$; Wagner \& Levin, 1978) and parasites are likely to be exposed to this oxygen tension as they reside in the host's urinogenital tract. Although hydrogen evolution by whole cells is known to be very sensitive to oxygen it has not been shown whether this is attributable to inhibition of the hydrogenase enzyme itself. For example, it was shown by Pow \& Krasna (1979) in green algae that oxygen inhibited hydrogen formation by cells but that this occurred under conditions where the hydrogenase itself was still active; it was concluded that oxygen inhibited the supply of electrons to the hydrogenase via an electron carrier. It has been reported that within the trichomonad hydrogenosomes there is another oxygensensitive enzyme, pyruvate:ferredoxin oxidoreductase (Lindmark \& Müller, 1973; Müller, 1990). Hence, the nature of the effect of oxygen on the hydrogenase itself has not been resolved. In this study we have used the tritium exchange assay, which is specific for the hydrogenase enzyme itself, to measure the effect of oxygen on the activity of hydrogenase directly and have compared this with the pattern of oxygen inhibition of hydrogen metabolism of whole cells. We have also determined whether hydrogen formation by isolated hydrogenosomes is as sensitive to oxygen as is the hydrogen formation by whole cells.

Oxygen-protection mechanisms in trichomonads are not well understood. As well as direct oxygen-scavenging activities such as those catalysed by $\mathrm{NAD}(\mathrm{P}) \mathrm{H}$ oxidases, they would presumably also include scavenging mechanisms for superoxide and hydrogen peroxide, toxic 
products of the reduction of oxygen by a variety of cellular processes. Hydrogen peroxide could be generated by the action of superoxide dismutase, which is known to exist in trichomonads; superoxide and hydrogen peroxide could arise from reactions in immune cells in the host in addition to that generated in the parasite itself. In many organisms, catalase is involved in the removal of hydrogen peroxide; cells also use peroxidases, which are effective in removing peroxide at low concentrations (Halliwell \& Gutteridge, 1989). Tritr. foetus has been shown to possess catalase activity (Ryley, 1955; Müller, 1973) but this enzyme has not been reported in Trich. vaginalis (Ryley, 1955; Ninomiya \& Suzuoki-Ziro, 1952). Glutathione peroxidase is found in many organisms but is not likely to be present in trichomonads, at least in Tritr. foetus, because glutathione is not present in this organism (Brown et al., 1993). Many micro-organisms, including Trypanosoma cruzi (Boveris et al., 1980), contain ascorbate peroxidase as a hydrogen peroxide scavenger.

The aims of this work were to answer two unresolved questions concerning the susceptibility of trichomonads to oxygen: (1) is the hydrogenase itself inactivated by oxygen, and (2) are catalase and ascorbate peroxidase both present in Tritr. foetus and Trich. vaginalis and what are their kinetic characteristics?

\section{METHODS}

Parasites. The human parasite Trichomonas vaginalis, an Australian isolate (WAA 38; Dr A. Warton, School of Biological Sciences, Macquarie University, Sydney), and the cattle parasite Tritrichomonas foetus (strain KV1) were kindly provided by Dr M. R. Edwards, School of Biochemistry and Molecular Genetics, University of New South Wales, Australia. The parasites were grown at $37^{\circ} \mathrm{C}$ in a modified tryptose/yeast extract/maltose (TYM) medium, as originally described by Diamond (1955), but maltose was replaced with $14 \mathrm{mM}$ glucose. Trich. vaginalis was grown at $\mathrm{pH} 6.2$ and Tritr. foetus at $\mathrm{pH} 7 \cdot 0$. Growth medium $(45 \mathrm{ml})$ was inoculated with cells $(0.5 \mathrm{ml}$ at a cell density of $5-15 \times 10^{6}$ cells $\mathrm{ml}^{-1}$ ) in $50 \mathrm{ml}$ polypropylene screw-capped tubes. For bulk culture this was scaled up to $8 \mathrm{ml}$ cells in $800 \mathrm{ml}$ culture flasks. The viability of the organisms was examined microscopically. Growth curves were obtained using a haemocytometer after fixing the cells before counting with $1 \%$ $(\mathrm{w} / \mathrm{v})$ paraformaldehyde and $0.5 \%$ sucrose in PBS $(0.145 \mathrm{M}$ $\mathrm{NaCl} ; 0 \cdot 15 \mathrm{M}$ sodium phosphate) at $\mathrm{pH} 7 \cdot 2$. Cells in the lateexponential phase (Tritr. foetus, 22-24 h; Trich. vaginalis, 46$48 \mathrm{~h}$ ) containing $5-15 \times 10^{6}$ cells $\mathrm{ml}^{-1}$ were harvested by centrifugation $\left(1465 \mathrm{~g}, 10 \mathrm{~min}, 4^{\circ} \mathrm{C}\right)$ in a Sorvall $\mathrm{RC}-2 \mathrm{~B}$ centrifuge with a GSA rotor.

Preparation of the hydrogenosomal fraction. The harvested cells were washed by centrifugation as above twice in sucrose $(250 \mathrm{mM})$ and once in homogenizing buffer containing sucrose $(250 \mathrm{mM}), \mathrm{KCl}(20 \mathrm{mM}), \mathrm{KH}_{2} \mathrm{PO}_{4}(10 \mathrm{mM}), \mathrm{MgCl}_{2}(5 \mathrm{mM})$ and $\mathrm{Tris} / \mathrm{HCl}(20 \mathrm{mM})$ adjusted to $\mathrm{pH} 7 \cdot 0$. The washed cells were then resuspended in approximately $5 \%(\mathrm{v} / \mathrm{v})$ of the homogenizing buffer in a Thomas size B glass homogenizer and homogenized with $40-50$ strokes of the teflon pestle at 900 r.p.m. at $4{ }^{\circ} \mathrm{C}$. The homogenate was then adjusted to a volume of $15 \mathrm{ml}$ with the same buffer and centrifuged as above for $5 \mathrm{~min}$. The supernatant was separated and kept on ice while unbroken cells were sedimented and subsequently homogenized under identical conditions. This homogenate was then com- bined with the supernatant and kept on ice. Almost $95 \%$ breakage was achieved.

The resulting homogenate was transferred into $30 \mathrm{ml}$ capacity screw-capped tubes and was subjected to differential centrifugation in a Sorvall RC-2B refrigerated centrifuge using an SS34 rotor. The nuclear fraction was sedimented $(755 \mathrm{~g}, 4 \mathrm{~min}$, $\left.4{ }^{\circ} \mathrm{C}\right)$ and removed. The supernatant was then centrifuged $(12100 \mathrm{~g}, 10 \mathrm{~min})$ and the sediment was washed once with sucrose $(250 \mathrm{mM})$ by centrifugation under identical conditions. The sediment obtained during this centrifugation step was the large particle fraction enriched in hydrogenosomes; it constituted about $14 \%$ of the total protein content as shown by Lindmark \& Müller (1973). This large particle fraction is referred to as the hydrogenosomal fraction. The activity of frozen hydrogenosomal fractions was investigated in comparison with that of freshly prepared hydrogenosomal fractions. A hydrogenosomal fraction that had been frozen for $48 \mathrm{~h}$ at $-20{ }^{\circ} \mathrm{C}$ retained about $80 \%$ of its hydrogen formation activity. The purity of the hydrogenosomal fraction was assessed by determining the activity of the hydrogenosomal marker enzyme malate dehydrogenase (decarboxylating) (Lindmark et al., 1975; Hrdy et al., 1993).

Maintenance of anoxic conditions. Experiments used to determine hydrogen gas formation were carried out under anoxic conditions. All the solutions for homogenizing and washing cells were sparged with argon for $30 \mathrm{~min}$ and kept in air-tight containers. Homogenization was performed under argon. The incubation media in $8.8 \mathrm{ml}$ vials (Pierce Chemical) were set up in a manifold system and flushed for $20 \mathrm{~min}$ with nitrogen which was passed through a hot copper column heated electrically to about $300^{\circ} \mathrm{C}$.

Measurement of hydrogen formation. Whole cells were incubated in PBS containing $\mathrm{NaH}_{2} \mathrm{PO}_{4}(30 \mathrm{mM}), \mathrm{NaCl}$ (74 mM), $\mathrm{CaCl}_{2}(0.6 \mathrm{mM}), \mathrm{KCl}(1.6 \mathrm{mM}), \mathrm{pH} 7.0$, and supplemented with glucose $(50 \mathrm{mM})$ (Cerkasovova et al., 1984). The hydrogenosomal incubation medium consisted of $\mathrm{KCl}(20 \mathrm{mM})$, $\mathrm{KH}_{2} \mathrm{PO}_{4}(10 \mathrm{mM}), \mathrm{MgCl}_{2}(5 \mathrm{mM})$ and Tris/ $\mathrm{HCl}(20 \mathrm{mM}), \mathrm{pH}$ $7 \cdot 0$, and was supplemented with freshly prepared pyruvate $(10 \mathrm{mM}), \mathrm{ADP}(1 \mathrm{mM})$ and succinate $(100 \mu \mathrm{M})$ (Cerkasovova $e t$ al., 1984). Incubation medium $(4 \mathrm{ml})$ as described above was transferred into the screw-capped $8.8 \mathrm{ml}$ vials. Different concentrations of oxygen were injected into the vials using a $1 \mathrm{ml}$ gastight syringe. This was followed by injecting $100 \mu \mathrm{l}$ sample (either whole cells or hydrogenosomal fraction) using a Hamilton microsyringe preflushed with argon. The sample was kept anoxically on ice prior to use. The vials were then incubated at $37^{\circ} \mathrm{C}$ with shaking at 100 oscillations $\mathrm{min}^{-1}$ (Steinbüchel \& Müller, 1986). Gas samples $(0 \cdot 2 \mathrm{ml})$ were taken from the vials using a $1 \mathrm{ml}$ disposable syringe (26-G needles), flushed with argon prior to use. While removing samples from the vials the syringes were pumped up and down five times, removed after about $50 \mathrm{~s}$, and inserted quickly into rubber stoppers. Samples were then analysed by gas chromatography (Daday et al., 1977).

Tritium exchange assay. Hydrogenase (EC class 1.12) activity was measured as tritium exchange activity. Incubation medium $(2.2 \mathrm{ml})$ was transferred into $8.8 \mathrm{ml}$ vials as above and rendered oxygen-free as described above. A sample $(100 \mu \mathrm{l})$ of cells $\left(0.5 \times 10^{6} \mathrm{cells} \mathrm{ml}^{-1}\right)$ was injected into the vials. For the oxygensensitivity test different concentrations of oxygen were introduced into the vials with a syringe. Details of the assay procedure are given by Ewart \& Smith (1989).

Catalase assay. Catalase (EC 1.11.1.6) activity was assayed in a Clark-type oxygen electrode (Rank Bros). The reaction 
mixture contained phosphate buffer $(50 \mathrm{mM}), \mathrm{pH} 7 \cdot 0$, hydrogen peroxide $(33.5 \mathrm{mM})$ and sample (homogenate or hydrogenosomal fraction) in a total volume of $3 \mathrm{ml}$. The temperature was maintained at $25^{\circ} \mathrm{C}$. During the assay, a stream of argon gas was bubbled through the buffer solution in the chamber by means of a hypodermic needle connected to the gas pressure regulator until all oxygen in the chamber was displaced. When the recorder registered zero oxygen, the system was allowed to equilibrate for a few minutes before adding $100 \mu \mathrm{l}$ hydrogen peroxide which was prepared in the same buffer and also bubbled with argon. The chamber was then rapidly stoppered to minimize diffusion of air. The samples which had been previously incubated with $1 \%(\mathrm{v} / \mathrm{v})$ Triton $\mathrm{X}-100$ at room temperature were then added to the chamber using a Hamilton microsyringe. Because the presence of $\mathrm{NAD}(\mathrm{P}) \mathrm{H}$ oxidases in the sample could reduce the apparent activity, the samples were first desalted prior to assaying to remove endogenous substrates. The desalting column was a Pharmacia NAP-10 column which was washed with the same phosphate buffer used for the enzyme assay. The evolution of oxygen was recorded as a measure of catalase activity (Rio et al., 1977; Nakano \& Asada, 1981).

Ascorbate peroxidase assay. Ascorbate peroxidase (EC 1.11.1.11) was assayed spectrophotometrically using a Varian Techtron 635 spectrophotometer at $290 \mathrm{~nm}$ and $25^{\circ} \mathrm{C}$. The reaction mixture contained potassium phosphate $(50 \mathrm{mM})$, pH 7.0, EDTA $(0.1 \mathrm{mM})$, ascorbate $(0.5 \mathrm{mM})$ and hydrogen peroxide $(0.1 \mathrm{mM})$ in a total volume of $3.0 \mathrm{ml}$. The reaction was started by adding the sample and the decrease in the absorbance was recorded 10-30 s after this addition (Nakano \& Asada, 1981). The samples were first desalted on a Pharmacia NAP-10 column.

Protein determination. Protein was determined by the Lowry method, adapted for microtitre plates. BSA was used as a standard.

Materials. Foetal calf serum was purchased from Cytosystems; tritium gas was obtained from Amersham; NAD and NADP were obtained from Boehringer Mannheim; hydrogen peroxide was obtained from BDM Chemicals; ADP and succinate were obtained from Sigma. All other chemicals were of analytical grade.

\section{RESULTS}

\section{Investigation of the effect of oxygen on hydrogen formation and hydrogenase activity}

A range of concentrations of oxygen was chosen to cover those of the physiological environment within the host. The uninfected human host's vaginal oxygen concentration has been reported to be 15-56 $\mu \mathrm{M}$ (Wagner \& Levin, 1978) but the vaginal oxygen concentrations of infected humans have not been reported; neither have the oxygen concentrations of the reproductive tract of cattle, infected or uninfected. In order to obtain a full inhibition profile, the oxygen concentration was extended well beyond this range. The profile of oxygen inhibition of whole-cell hydrogen formation is shown in Fig. 1.

The tritium exchange reaction involves a phase transfer step, the substrate being a gas and the product being in the liquid phase. It was therefore necessary to choose assay conditions in which this phase transfer step was not ratelimiting. Hence the rate of tritium exchange was measured as a function of both time and cell concentration. The phase transfer was not rate-limiting up to a cell con-

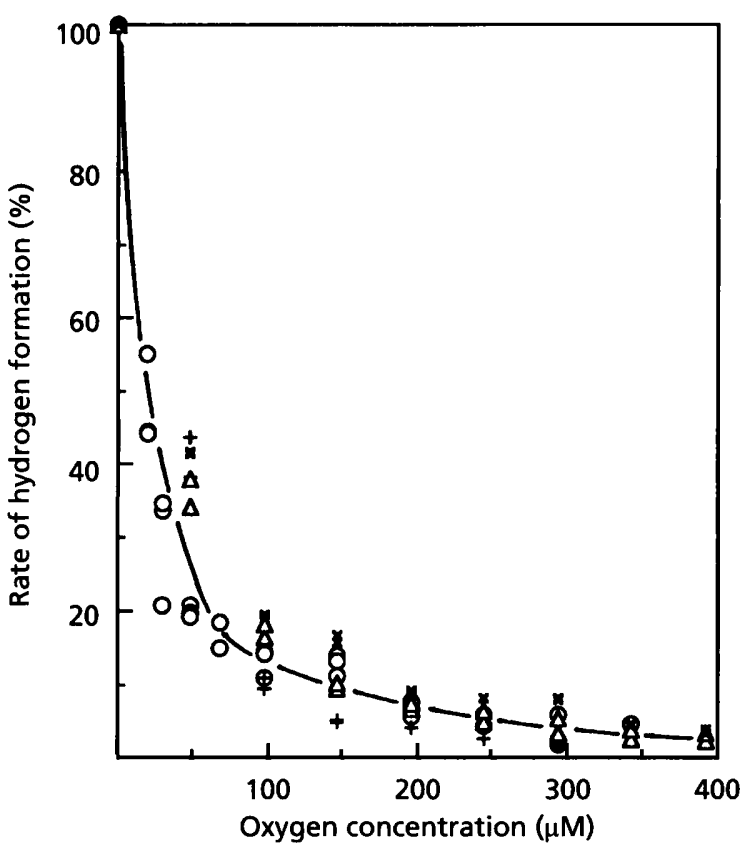

Fig. 1. Effect of oxygen on the rate of hydrogen formation by whole cells $(O)$ and hydrogenosomes $(+)$ of Tritr. foetus, and the rate of tritium exchange activity of whole cells of Tritr. foetus $(\triangle)$ and Trich. vaginalis $(x)$. The mean anoxic rates of hydrogen formation by whole cells and hydrogenosomes of Tritr. foetus were $0.84 \mu \mathrm{mol} \mathrm{h}^{-1}$ (mg protein) ${ }^{-1}$ and $1.9 \mu \mathrm{mol} \mathrm{h}^{-1}$ (mg protein $)^{-1}$, respectively. The anoxic rates of tritium exchange activity of whole cells of Tritr. foetus and Trich. vaginalis were 973 c.p.m. and 713 c.p.m., respectively, both with a cell density of $0.5 \times 10^{6}$ cells $\mathrm{ml}^{-1}$.

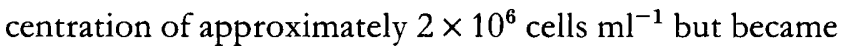
so above this concentration; i.e. the rate of tritium exchange became zero-order with respect to enzyme concentration. Hence a cell concentration of $5 \times 10^{5}$ cells $\mathrm{ml}^{-1}$ was used in subsequent experiments. In these experiments it was not necessary to determine the degree of cellular isotopic quenching because the same number of cells was used at each oxygen concentration and therefore the relative magnitude of oxygen inactivation would not be artefactually affected by quenching. The oxygen inhibition profile for inhibition of tritium exchange activity is also shown in Fig. 1. It is clear that the profiles for inhibition of hydrogen production by whole cells and inhibition of tritium exchange activity are similar, indicating that inhibition of hydrogenase itself is the most probable cause of the inhibition of whole-cell hydrogen production.

\section{The profile of oxygen inhibition of hydrogenosomal hydrogen formation}

The pattern of hydrogenosomal hydrogen formation is also shown in Fig. 1. This was measured in order to investigate whether there are oxygen protection mechanisms in the cytoplasm which protect the hydrogenosomes. The fact that the profiles for each virtually coincide indicates that this is not the case. 


\section{Activities of catalase and ascorbate peroxidase}

Catalase activity was confirmed to be present in Tritr. foetus, but not Trich. vaginalis. Its specific activity was $21 \pm 3 \mu \mathrm{mol} \min ^{-1}(\mathrm{mg} \text { protein })^{-1}($ mean $\pm \mathrm{sD}, n=5)$. Ascorbate peroxidase activity was present in both Tritr. foetus and Trich. vaginalis [specific activities $0.43 \pm 0.05 \mu \mathrm{mol} \mathrm{min}^{-1}$ (mg protein) $)^{-1}$ (mean $\pm \mathrm{SD}, n=5$ ) and $0.36 \pm 0.03 \mu \mathrm{mol} \mathrm{min}^{-1}$ (mg protein) ${ }^{-1}$ (mean $\pm \mathrm{sD}, n$ $=5$ ), respectively], with approximately $18 \%$ of the total activity present in the hydrogenosomal fraction. Kinetic analysis of the two enzymes revealed a hyperbolic function with respect to substrate concentration. The apparent $K_{\mathrm{m}}$ values for catalase and ascorbate peroxidase in Tritr. foetus were $55 \pm 4$ (mean $\pm \mathrm{sD}, n=5) \mathrm{mM}$ and $35 \pm 9$ (mean $\pm \mathrm{sD}$, $n=5) \mu \mathrm{M}$, respectively. The $K_{\mathrm{m}}$ of the Trich. vaginalis ascorbate peroxidase was $49 \pm 13$ (mean $\pm \mathrm{SD}, n=5) \mu \mathrm{M}$.

\section{DISCUSSION}

The physiological oxygen concentration range to which Tritr. foetus could be exposed is $15-56 \mu \mathrm{M}$ (Wagner \& Levin, 1978). Over this oxygen concentration range the rate of hydrogen evolution by whole cells was substantially less than the anoxic rate (Fig. 1), the 50\% inhibition concentration being about $25 \mu \mathrm{M}$. The pattern of oxygen inhibition of the hydrogenase itself was not distinguishable, within experimental error, from that on whole-cell hydrogen formation. This is consistent with the hydrogenase being a primary site of oxygen inhibition of anaerobic metabolism and supports the results of Ellis et al. (1992), who showed in Trich. vaginalis that hydrogenase activity was inhibited to a greater extent than pyruvate:ferredoxin oxidoreductase activity at $20 \mu \mathrm{M}$ oxygen. Almost complete inhibition of hydrogenase activity was observed at ambient oxygen concentrations $(195 \mu \mathrm{M})$. A similar pattern of inhibition was found for the hydrogenase in Trich. vaginalis (Fig. 1).

As shown in Fig. 1, within experimental accuracy the pattern of oxygen inhibition of hydrogen formation was similar in whole cells and in isolated hydrogenosomes, implying that whole cells offer no protection from oxygen over that available to the hydrogenosomes, in which the hydrogenase is located. Although the cytoplasm of the cells is known to contain NADH and NADPH oxidases (Müller, 1990), their primary function may be to dispose of surplus electrons generated by fermentative metabolism rather than to protect against oxygen.

In this work we also investigated the enzymes of hydrogen peroxide removal. Catalase activity was not detected in Trich. vaginalis, confirming what has been previously reported (Müller, 1990). We have also confirmed its presence in Tritr. foetus and have shown that both organisms contain ascorbate peroxidase. In Tritr. foetus the $K_{\mathrm{m}}$ value of catalase for hydrogen peroxide was much greater $(55 \mathrm{mM})$ than that of ascorbate peroxidase $(35 \mu \mathrm{M})$. The $K_{\mathrm{m}}$ of catalase from other sources varies from 47 to $1100 \mathrm{mM}$ (Miyake et al., 1991). Catalase is the more efficient enzyme at a higher hydrogen peroxide concentration [a specific activity of about $21 \mu \mathrm{mol} \mathrm{min}{ }^{-1}$ (mg protein) $)^{-1}$ compared with about $0.43 \mu \mathrm{mol} \mathrm{m^{-1 }}$ (mg protein $)^{-1}$ for ascorbate peroxidase], whereas at low hydrogen peroxide concentrations ascorbate peroxidase would take over as the relatively more effective enzyme. Hence, as in many micro-organisms (Nakano \& Asada, 1981; Miyake et al., 1991), catalase is likely to play the role of efficiently removing most of any hydrogen peroxide that accumulates, with ascorbate peroxidase scavenging low concentrations of residual hydrogen peroxide. The kinetic properties of this enzyme in both Tritr. foetus and Trich. vaginalis were similar. It is not known why Trich. vaginalis does not have catalase. Perhaps Trich. vaginalis does not encounter the same levels of hydrogen peroxide in vivo as does Tritr. foetus but there is no evidence for this to our knowledge.

The question of whether hydrogenase is the primary site of inhibition of hydrogen formation is pertinent to other organisms which produce hydrogen. It appears that the situation in the trichomonads is quite different from that in green algae, for example, where oxygen was shown to inhibit whole-cell hydrogen formation under conditions in which the hydrogenase itself was still active (Pow \& Krasna, 1979). This is not necessarily surprising, since in the algae hydrogen production is driven by electron flow through the photosynthetic membranes, whereas in the trichomonads hydrogen production is fermentative. It is also well known that hydrogenases from different sources vary markedly in their sensitivity to oxygen, some being totally irreversibly inhibited, others reversibly inhibited and yet others relatively unaffected (Adams et al., 1981).

\section{REFERENCES}

Adams, M. W. W., Mortenson, L. E. \& Chen, J.-S. (1981). Hydrogenase. Biochim Biophys Acta 594, 105-176.

Boveris, A., Sies, H., Martino, E. E., Docampo, R., Turrens, J. F. \& Stopani, A. O. M. (1980). Deficient metabolic utilization of hydrogen peroxide in Trypanosoma cruzi. Biochem $J$ 188, 643-648.

Brown, D. M., Upcroft, J. A. \& Upcroft, P. (1993). Cysteine is the major low-molecular weight thiol in Giardia duodenalis. Mol Biochem Parasitol 61, 155-158.

Cerkasovova, A., Cerkasov, J. \& Kulda, J. (1984). Metabolic differences between metronidazole resistant and susceptible strains of Tritrichomonas foetus. Mol Biochem Parasitol 11, 105-118.

Daday, A., Platz, R. A. \& Smith, G. D. (1977). Anaerobic and aerobic hydrogen formation by the blue-green alga Anabaena cylindrica. Appl Environ Microbiol 34, 478 483.

Diamond, L. S. (1955). The establishment of various trichomonads of animals and man in axenic cultures. $J$ Parasitol 43, 488-490.

Ellis, J. E., Cole, D. \& Lloyd, D. (1992). Influence of oxygen on the fermentative metabolism of metronidazole-sensitive and resistant strains of Trichomonas vaginalis. Mol Biochem Parasitol 56, 79-88.

Ewart, G. D. \& Smith, G. D. (1989). Purification and properties of soluble hydrogenase from the cyanobacterium Anabaena cylindrica. Arch Biochem Biopbys 268, 327-337.

Halliwell, B. \& Gutteridge, J. M. C. (1989). Free Radicals in Biology and Medicine, 2nd edn. Oxford: Oxford University Press.

Hrdy, I., Mertens, E. \& Van Schaftingen, E. (1993). Identification, purification and separation of different isoenzymes of NADPspecific malic enzyme from Tritrichomonas foetus. Mol Biochem Parasitol 57, 253-260. 
Lindmark, D. G. \& Muller, M. (1973). Hydrogenosome, a cytoplasmic organelle of the anaerobic flagellate, Tritrichomonas foetus, and its role in pyruvate metabolism. J Biol Chem 248, 7724-7728.

Lindmark, D. G., Müller, M. \& Shio, H. (1975). Hydrogenosomes in Trichomonas vaginalis. J Parasitol 61, 552-554.

Lloyd, D. \& Kristensen, B. (1985). Metronidazole inhibition of hydrogen production in vivo in drug-sensitive and resistant strains of Trichomonas vaginalis. J Gen Microbiol 131, 849-853.

Miyake, C., Michihata, F. \& Asada, K. (1991). Scavenging of hydrogen peroxide in prokaryotic and eukaryotic algae: acquisition of ascorbate peroxidase during the evolution of cyanobacteria. Plant Cell Physiol 32, 33-43.

Müller, M. (1973). Biochemical cytology of trichomonad flagellates. I. Subcellular localization of hydrolases, hydrogenase and catalase in Tritrichomonas foetus. J Cell Biol 57, 453-474.

Müller, M. (1990). Biochemistry of Trichomonas vaginalis. In Trichomonads Parasitic in Humans, pp. 53-83. Edited by B. M. Honigberg. New York: Springer-Verlag.

Nakano, Y. \& Asada, K. (1981). Hydrogen peroxide is scavenged by ascorbate-specific peroxidase in spinach chloroplasts. Plant Cell Pbysiol 22, 867-880.
Ninomiya, H. \& Suzuoki-Ziro (1952). The metabolism of Trichomonas vaginalis, with comparative aspects of trichomonads. J Biocbem 39, 321-331.

Pow, T. \& Krasna, A. I. (1979). Photoproduction of hydrogen from water in hydrogenase-containing algae. Arch Biochem Biopbys 194, 413-421.

Rio, L. A. D., Ortega, M. G., Lopez, A. L. \& George, J. L. (1977). A more sensitive modification of the catalase assay with the Clark oxygen electrode. Anal Biochem 80, 409-415.

Ryley, J. F. (1955). Studies on the metabolism of the protozoa. 5. Metabolism of the parasitic flagellate Trichomonas foetus. Biochem $J$ 59, 361-369.

Steinbuchel, A. \& Muller, M. (1986). Glycerol, a metabolic end product of Trichomonas vaginalis and Tritrichomonas foetus. Mol Biochem Parasitol 20, 45-55.

Wagner, G. \& Levin, R. (1978). Oxygen tension of the vaginal surface during sexual stimulation in the human. Fertil Steril 30, 50-53.

Received 30 December 1994; revised 29 August 1995; accepted 6 September 1995. 